logos_i_ethos_2015_1_(38), s. 59-80

DOI: http://dx.doi.org/10.15633/lie.1045

Teresa Obolevitch

Uniwersytet Papieski Jana Pawła II w Krakowie

\title{
Gieorgija Fłorowskiego krytyka rosyjskiego renesansu religijno-filozoficznego: próba oceny ${ }^{1}$
}

Gieorgij Fłorowski (1893-1979) należy do grona osób, które wywarły istotny, by nie powiedzieć - decydujący wpływ na oblicze rosyjskiej kultury intelektualnej XX wieku.

Teresa Obolevitch - dr hab. filozofii, kierownik katedry Filozofii religii na Wydziale Filozoficznym UPJPII w Krakowie, członek Centrum Kopernika Badań Interdyscyplinarnych. Ten wybitny filozof, teolog, aktywny uczestnik ruchu ekumenicznego, autor licznych prac poświęconych myśli rosyjskiej i patrystycznej, wychowawca kilku pokoleń znakomitych intelektualistów (zarówno Rosjan-emigrantów, jak i zachodnich badaczy) znany jest przede wszystkim jako odnowiciel tradycji patrystycz$n^{2}{ }^{2}$ (bądź inicjator tzw. syntezy neopatrystycznej) w ubiegłym stuleciu. Wywarł on wpływ nie tylko na kształt rosyjskiej kultury filozoficzno-teologicznej, ale także przyczynił się (wraz z wieloma katolickimi i protestanckimi teologami) do „zwrotu patrystycznego” w ubiegłym stuleciu. W niniejszym tekście skupimy się przede wszystkim na tym, jak Fłorowski postrzegał dziedzictwo myśli rosyjskiej oraz współczesne mu zjawisko tzw. renesansu religijno-filozoficznego, odznaczającego się nie tyle odrodzeniem (co sugeruje słowo „renesans”), ile narodzeniem oryginalnej rosyjskiej myśli filozoficznej (najpierw w samej Rosji, a po rewolucji październikowej - przeważnie na emigracji). Tej problematyce poświęcona

Artykuł powstał w ramach grantu „Nauka, filozofia i polityka w rosyjskiej myśli religijnej” przyznanego przez Narodowe Centrum Nauki, UMO-2014/15/B/HS1/01620.

Zob. R. J. Sauvé, Florovsky's Tradition, „Greek Orthodox Theological Review” 55 (2010) nr 1-4, s. 213. 
została książka amerykańskiego badacza ukraińskiego pochodzenia, Paula Gavrilyuka33, a także niektóre rozdziały mojej pracy dotyczącej twórczości o. Gieorgija Fłorowskiego i Włodzimierza Łosskiego ${ }^{4}$. Ciągle jednak ukazują się kolejne materiały, które rzucają nowe światło na kwestię stosunku Fłorowskiego do rosyjskiej tradycji filozoficzno-religijnej, a także roli, którą on odegrał w procesie kształtowania się ruchu neopatrystycznego. Ponadto warto zestawić myśl Fłorowskiego z dorobkiem innego autora emigracyjnego, Wasyla Zieńkowskiego, który, podobnie jak tamten, podzielał jego krytyczne podejście do stylu rosyjskiego filozofowania, mimo że nie negował samej idei filozofii religijnej.

\section{Ocena sytuacji religijno-filozoficznej}

Swój stosunek do rosyjskiego renesansu religijno-filozoficznego Fłorowski przedstawił w esejach poświęconych twórczości jego „ojca”, Włodzimierza Sołowjowa (1853-1900) oraz innych rosyjskich myślicieli Srebrnego Wieku, takich jak Paweł Florenski ${ }^{5}$ (1882-1937) i Sergiusz Bułgakow (1871-1944). Szczególną okazją do zabrania głosu na ten temat był toczący się w latach 30 . zeszłego wieku spór wokół sofiologii, w którym opinia Fłorowskiego odegrała niepoślednią rolę. Warto także odnotować jego fundamentalną pracę Drogi teologii rosyjskiej (1937) oraz niedawno opublikowany, archiwalny tekst Filozofia rosyjska na emigracji (ukończony w 1930, a więc powstały mniej więcej w tym samym czasie, co wyżej wymieniona książka, choć zawierający nieco odmienną, bardziej łagodną ocenę rozwoju współczesnej Fłorowskiemu myśli rosyjskiej).

Zacznijmy od symptomatycznej oceny stanu rosyjskiej kultury intelektualnej Srebrnego Wieku zaprezentowanej przez Fłorowskiego w Drogach. Autor pisze:

3 P. L. Gavrilyuk, Georges Florovsky and the Russian religious renaissance, Oxford 2013.

4 T. Obolevitch, Filozofia rosyjskiego renesansu patrystycznego: o. Gieorgij Fłorowski, Włodzimierz Łosski i inni, Kraków 2014.

Mimo niezgodności z zasadami transkrypcji i niekonsekwencji z zapisem innych analogicznych nazwisk, w artykule zastosowano pisownię Florenski, gdyż ta właśnie upowszechniła się w literaturze przedmiotu [przyp. red.]. 
Powstaje u nas filozofia religijna jako szczególny rodzaj filozoficznego wyznania i działania. Był to powrót metafizyki do źródeł religijnych. [...] Sama psychologia filozofów staje się u nas wówczas religijną. [...] W sposób religijny zostają przekształcone u nas także inne wpływy filozoficzne: fenomenologia Husserla, odrodzenie wielkich systemów idealistycznych ${ }^{6}$.

Zarazem Fłorowski zaznacza, że odrodzenie religijno-filozoficzne końca XIX i pierwszych dekad XX wieku niejednokrotnie miało charakter gnostycki, odbiegający od nauki chrześcijańskiej. W rezultacie filozofia zajęła miejsce teologii. Jedynie Florenski i Bułgakow zbliżyli się do problematyki teologicznej, ale także oni przekroczyli granice ortodoksji, głosząc naukę o Sofii - Mądrości Bożej pełniącej rolę pośrednika między Bogiem a światem stworzonym. Autor Dróg teologii rosyjskiej dużo zawdzięczał obydwom wymienionym myślicielom (w szczególności, dzięki zaproszeniu o. Sergiusza Bułgakowa został wykładowcą patrologii w Instytucie św. Sergiusza w Paryżu), jednakże to właśnie Fłorowski stał się jednym z ekspertów, który miał dokonać ( $\mathrm{z}$ polecenia metropolity Eulogiusza) oficjalnej oceny sofiologii. W 1936 roku podpisał sporządzony przez o. Siergieja Czetwerikowa dokument - tzw. szczególną opinię (особое мнение), w którym zostało stwierdzone, że nauka o Sofii zawiera poglądy niebezpieczne, wręcz heretyckie, niezgodne z Pismem Świętem i tradycją ojców Kościoła.

Co więcej, w ocenie Fłorowskiego nie tylko filozofia, ale także teologia rosyjska, która ukształtowana została pod wpływami innych tradycji (najpierw w otwartej w XVII wieku Akademii Kijowsko-Mohylańskiej - łacińsko-katolickiej, a następnie, od czasów Piotra I niemiecko-protestanckiej) zaprzepaściła dziedzictwo patrystyczne właściwe dla kultury bizantyjsko-słowiańskiej.

Nauka teologiczna była zaszczepiona w Rosji z Zachodu. Zbyt długo pozostawała ona w Rosji obca, uparcie mówiła w swym specyficznym i obcym języku (nie w języku codziennym i języku modlitw). [...] Dociekanie teologiczne nie mogło 
znaleźć dla siebie gruntu. [...] W teologii patrystyczny styl i metoda zostały porzucone, a dzieła Ojców stały się martwym historycznym dokumentem... ${ }^{7}$.

W kulturze Srebrnego Wieku, odznaczającej się powstaniem wielkich systemów filozoficznych autorstwa Sołowjowa i innych myślicieli, dokonał się „spóźniony i niepotrzebny powrót z Jerozolimy do Aten”. Tymczasem powinien dokonywać się proces odwrotny: nie restauracji greckiego sposobu filozofowania (nawet w duchu idealizmu), lecz chrystianizacji myśli filozoficznej, przepojenia jej treścią Objawienia, jak to miało miejsce w okresie patrystycznym. „Trzeba stworzyć duchową «filozofię serca» - pisał Fłorowski, streszczając myśl Michała Tarejewa - i nawet jeśli ona nie zastąpi, to przysłoni teologię dogmatyczną, typowy wytwór greckiego intelektualizmu” . Warto wspomnieć, że „filozofia serca” w Rosji ma dość długą tradycję, m.in. była ona uprawiana przez Pamfiła Jurkiewicza (ok. 1826/27-1874), promotora pracy magisterskiej „ojca” myśli rosyjskiej, Włodzimierza Sołowjowa, a także Pawła Florenskiego ${ }^{10}$. Jednak na ogół w XIX i XX wieku kontynuowany był proces „okcydentalizacji” zarówno teologii, jak i filozofii, co wprawdzie zaowocowało stworzeniem imponujących systemów religijno-filozoficznych, lecz zarazem odejściem od korzeni rosyjskiego prawosławia. Według słów Fłorowskiego:

Teolog prawosławny jak dotąd zanadto zależy w swej własnej pracy twórczej od wsparcia Zachodu. Swe źródła otrzymuje właśnie z rąk zachodnich, czyta Ojców i dzieje Soborów w zachodnich (często wzorcowych) wydaniach, zapoznaje się $\mathrm{z}$ metodą i techniką posługiwania się zgromadzonym materiałem w szkole zachodniej. Także przeszłość naszego Kościoła znamy przeważnie dzięki wysiłkom wielu

$\begin{array}{ll}7 & \text { Tamże, s. } 492-493,496 . \\ 8 & \text { Tamże, s. } 501 . \\ 9 & \text { Tamże. } \\ 10 & \text { Zob. J. Kroczak, Palamas i Florenski. Metafizyka serca } w \text { patrystycznej i rosyjskiej }\end{array}$ tradycji filozoficznej i literackiej, [w:] Metafizyka a literatura $w$ kulturze rosyjskiej. Mетабизика и литература в русской культуре, red. T. Obolevitch, Kraków 2012, s. 311-326. 
pokoleń zachodnich badaczy i uczonych. [...] Do tego świata teolog prawosławny winien wnieść swe własne świadectwo ${ }^{11}$.

Co Fłorowski miał na myśli, pisząc o wysuwanym przez Tarejewa postulacie restauracji „filozofii serca”? Otóż myśliciele rosyjscy nawoływali nie tyle do „irracjonalizacji” uprawiania filozofii i teologii, ile do odnowienia stylu patrystycznego polegającego na harmonijnym łączeniu refleksji intelektualnej z żywym postrzeganiem Boga danym w egzystencjalnym doświadczeniu religijnym.

System teologiczny nie może być jedynie owocem uczoności, zrodzić się z namysłu filozoficznego. Potrzebne jest także doświadczenie modlitwy, duchowe skupienie, duszpasterskie przejęcie. [...] Teolog winien mówić do żywych osób, żywego serca, winien mówić w aspekcie czułej uwagi [сердечное внимание] i miłości [...]. W poznaniu jako takim jest i powinien być obecny nie tyle dialektyczny, ile dialogiczny moment ${ }^{12}$.

Jednostronna, wyłącznie spekulatywna formacja rosyjskiej myśli filozoficzno-teologicznej Srebrnego Wieku, pomijająca aspekt ascetyczno-mistyczny, sprawia - według diagnozy Fłorowskiego - że zostaje ona pozbawiona perspektywy swego dalszego owocnego rozwoju. Właśnie $\mathrm{z}$ tego powodu autor Dróg postulował zwrot w stronę zapomnianego i zaniedbanego w Rosji dziedzictwa ojców Kościoła i stworzenie syntezy neopatrystycznej.

\section{Uwagi krytyczne}

W tym miejscu warto rozważyć następującą kwestię: na ile Fłorowski, oceniając współczesny mu stan myśli rosyjskiej w kategoriach „zabłąkania” i wskazując na tradycję patrystyczną jako remedium na

11 Г. Флоровский, Пути русского богословия, dz. суt., s. 505.

12 Tamże, s. 508. 
zaistniałą sytuację, miał rację? Odpowiadając na postawione pytania, należy poczynić cztery uwagi.

Po pierwsze, Fłorowski - jak przytomnie zauważa Gavrilyuk - „był nie tylko krytykiem, ale także uczniem renesansu religijno-filozoficznego”, „jako myśliciel był pobudzony przez renesans, a jako uczony ukształtował się pod osobistym wpływem działaczy renesansu i wraz z nimi przecierpiał i przemyślał religijno-filozoficzne zagadnienia renesansu"13. Istotnie, omawiany autor nie jawił się jako outsider względem krytykowanego przez siebie stylu rosyjskiego filozofowania, ale występował „z wnętrza” renesansu, był jego aktywnym uczestnikiem, a nawet - do pewnego stopnia - współtwórcą emigracyjnego ruchu odrodzenia religijno-filozoficznego. Jak sam pisał: „rosyjska filozoficzna «diaspora» oznacza nowy moment, nowy etap w ciągłym historycznym losie myśli rosyjskiej"14.

Poddając krytyce stare drogi rozwoju myśli rosyjskiej i nawołując do poszukiwania nowych (a następnie proponując konkretny kierunek w postaci neopatrystyki), Fłorowski nie tyle odrzucał dotychczasowy dorobek swoich poprzedników i współczesnych autorów, ile pragnął wzmocnić jego chrześcijański fundament, „wybudowany”, by tak powiedzieć, z kamieni znalezionych na polu wschodniochrześcijańskiej tradycji ojców Kościoła. Przecież już Sołowjow, a w jeszcze większym stopniu o. Florenski i o. Bułgakow w swej twórczości chętnie nawiązywali do dziedzictwa patrystycznego, nawet jeśli nie wykorzystywali go w pełni i pozwalali sobie na wolne, ściśle filozoficzne interpretacje niektórych wątków obecnych u ojców Kościoła (przykładem może służyć koncepcja Sofii - Mądrości Bożej ${ }^{15}$ ). Sam Fłorowski uznawał, że rozpoczęty przez Sołowjowa

13 П. Л. Гаврилюк, Неизвестная странииза историко-философского наследия Г.В. Флоровского, [w:] Историко-философский ежегодник 2013, ред. А. В. Черняев, Москва 2014, s. 304.

14 Г. В. Флоровский, Русская философия в эмиграции, [w:] Историко-философский ежегодник 2013, dz. cyt., s. 314.

15 Fłorowski wyróżniał dwie koncepcje sofiologii - „kościelną”, sięgającą ojców wschodniochrześcijańskich i gnostycką, obecną w myśli Sołowjowa i jego następców. Zob. list G. Fłorowskiego do o. S. Bułgakowa z 22.07.1926 („Я не знаю, насколько тверды и самоотверженны миряне парижские...”: пятнадияать писем друг другу. Письма. Г.В. Флоровский - о. С. Булгакову 
„nowy ruch religijno-filozoficzny” podążał - poprzez niemiecki idealizm i „wielki niemiecki mistycyzm” - do platonizmu, a stamtąd - do świata patrystyki ${ }^{16}$. Warto także zauważyć, że powstała w XX wieku teistyczna filozofia egzystencjalna - uprawiana zarówno w kręgach zachodnich filozofów (Gabriel Marcel, Paul Tillich), jak i rosyjskich myślicieli (Mikołaj Bierdiajew) i skądinąd krytykowana przez Fłorowskiego, w wielu punktach jest zbliżona do egzystencjalnie i personalistycznie zorientowanej myśli Grzegorza Palamasa oraz innych ojców Kościoła ${ }^{17}$.

Zdaniem Fłorowskiego zasadniczy problem polegał na tym, że dotychczasowa „filozofia prowadziła do teologii, a nie wychodziła $z$ teologii”'18, podczas gdy on postulował kierunek odwrotny, zmierzający od teologii patrystycznej w stronę filozofii chrześcijańskiej - tzw. hellenizmu chrześcijańskiego. W tym duchu Fłorowski oceniał poszczególnych przedstawicieli renesansu religijno-filozoficznego, począwszy od Sołowjowa. Z jednej strony pochwalał ich wysiłki mające na celu pojednanie fides i ratio (co miało niebagatelne znaczenie w dobie panowania pozytywizmu i rozmaitych form materializmu), z drugiej zaś strony uważał, iż dotychczasowe próby nie odniosły zamierzonego skutku, albowiem „racjonalne usprawiedliwienie prawd wiary” (według zamysłu Sołowjo$\mathrm{wa}^{19}$ ) zbytnio skupiało się na elemencie rozumowym, pozostawiając na boku życie wiary. Innymi słowy, akcent był położony (także w dociekaniu teologicznym) na filozofię, a nie na teologię pojmowaną - w duchu ojców Kościoła - jako „teoria”, czyli widzenie, doświadczenie Boga. Lex orandi winno iść w parze z lex credendi, a nawet je poprzedzać.

(1925-1943)), [w:] Софиология и неопатристический синтез. Богословские итоги философского развития, ред. К. М. Антонов, Н. А. Ваганова, Москва 2013, s. 144.

16 Zob. Г. В. Флоровский, Русская философия в эмиграции, dz. суt., s. 325.

17 Zob. В. П. Визгин, Экзистенциализм и богословская мысль Георгия Флоровского, „Философский журнал” 2 (2014), s. 32-36.

18 Por. Г. В. Флоровский, Русская философия в эмиграции, dz. суt., s. 325.

19 Zob. List Włodzimierza Sołowjowa do Katarzyny Selewinej z 02.08.1873, [w:] Пucbма Владимира Сергеевича Соловьева, т. 3, Брюссель 1970, s. 89; tenże, История и будущность теократии, [w:] Собрание сочинений Владимира Сергеевича Соловьева, т. 4, Брюссель 1966, s. 214. 
W eseju Rosyjska filozofia na emigracji Fłorowski stwierdził, że myśl rosyjska znajduje się in statu nascendi, w procesie poszukiwania i walki, zaznaczając, że „w tej charakterystyce nie ma nic ubliżającego i ona nie świadczy o chaotyczności czy braku uformowania rosyjskiego duchu” ${ }^{20}$. Istnieją bowiem podstawy do „filozoficznego przełomu, nowego wybuchu twórczości”, a powyższe „przeczucie syntezy jest źródłem natchnienia rosyjskich poszukiwań" ${ }^{21}$. W Drogach teologii rosyjskiej napisanych kilka lat później autor był już znacznie bardziej zdecydowany, zaznaczając, że czas do stworzenia owej długo oczekiwanej syntezy już nadszedł, i że ma ona polegać na radykalnej zmianie paradygmatu i odważnym zwrocie w stronę teologicznych dociekań ojców Kościoła, które powinny nadawać kształt także filozoficznym poszukiwaniom. To teologia winna inspirować refleksję filozoficzną, a nie - jak poprzednio - jedynie korzystać $\mathrm{z}$ „usług” dostarczanych przez narzędzia filozoficzne.

Podsumowując dotychczasowe obserwacje, należy powiedzieć, że Fłorowski w swej diagnozie renesansu religijno-filozoficznego zajmował pozycję niejednoznaczną. Czytając poszczególne fragmenty jego pism (zwłaszcza zawarte w Drogach teologii rosyjskiej), odnosi się wrażenie, że był on nadzwyczaj surowym sędzią współczesnego mu ruchu intelektualnego. Jednak bardziej wnikliwa analiza całokształtu jego twórczości pozwala nieco złagodzić tę opinię. Fłorowski doceniał samą ideę poszukiwań filozoficzno-teologicznych podejmowanych przez Sołowjowa i jego następców, a jego „kąśliwe” wypowiedzi pod ich adresem dobitnie świadczą, że los myśli rosyjskiej był mu nieobojętny. Owszem, niekiedy dość kategorycznie, a nawet niesprawiedliwie oceniał przedstawicieli renesansu religijno-filozoficznego - także w świetle jego własnych, gdzie indziej zawartych analiz - lecz na pewno dążył nie tyle do całkowitego zburzenia dotychczasowego gmachu rosyjskiej myśli filozoficznej, ile do korekty istniejących projektów, a mianowicie, do wzmocnienia w nich

20 Г. В. Флоровский, Русская философия в эмиграции, dz. суt., s. 336.

$21 \quad$ Por. tamże, s. 337. 
fundamentu patrystycznego. Głosił bowiem, że „Zwróć się w kierunku patrystyki” oznacza nie tyle „iść do tyłu” w stronę ojców Kościoła, ile „iść do przodu wraz z Ojcami” 22 .

Łukasz Leonkiewicz jest bardziej stanowczy w swej charakterystyce przedsięwzięcia Fłorowskiego. W jego opinii „rosyjska myśl religijna i teologia neopatrystyczna mają się do siebie tak, jak neoplatonizm i teologia bizantyjska"23. Jeżeli się uwzględni, że różne formy platonizmu były potępiane w Kościele bizantyjskim jako heretyckie, to stanowiska renesansu religijno-filozoficznego i neopatrystyki polaryzują się jeszcze bardziej. Powtórzmy raz jeszcze: owszem, Fłorowski nie szczędził słów krytyki pod adresem pierwszego z wymienionych kierunków, jednak można wskazać także na liczne wzajemne przenikania się zarówno neoplatonizmu i teologii bizantyjskiej, jak też rosyjskiej myśli religijnej i neopatrystyki. Sam Fłorowski odbył przecież formację filozoficzną u wybitnych myślicieli Srebrnego Wieku, a w dalszym ciągu swej twórczości głosił tezę o „hellenizmie chrześcijańskim”, czyli pewnej adaptacji greckich kategorii filozoficznych dla potrzeb teologii chrześcijańskiej, co właśnie miało miejsce w okresie patrystycznym. Warto także przypomnieć, że nie zawsze platonizm był traktowany jako synonim herezji. Oficjalne potępienie platonizmu w Kościele wschodnim sięga VI wieku i trwało aż do schyłku Bizancjum, jednak wcześniej to nikt inny jak Platon był ukazywany jako „chrześcijanin przed Chrystusem”. Zresztą, nawet u myślicieli bizantyjskich, takich jak św. Maksym Wyznawca, znajdujemy sporo motywów platońskich. Mutatis mutandis, również myśl rosyjska (nawiązująca do linii platońskiej) nie musi być rozpatrywana jako heretycka w całej swej rozciągłości i być przeciwstawiana ortodoksyjnej linii (neo)patrystycznej.

Rzecz jasna, można traktować renesans religijno-filozoficzny i syntezę neopatrystyczną jako dwa antagonistyczne względem siebie

22 Zob. Г. Флоровский, Пути русского богословия, dz. cyt., s. 496.

23 Ł. Leonkiewicz, Czy neopatrystyka była rosyjskim renesansem patrystycznym, http:// www.ccpress.pl/recenzje/_Filozofia_rosyjskiego_renesansu_patrystycznego__-_rec._ks._dr._Lukasza_Leonkiewicza_81 (01.04.2015). 
projekty (co explicite czynił Fłorowski), jednak nie sposób nie dostrzec pomiędzy nimi licznych związków - wszak także ojcowie Kościoła, do których nawoływał autor Dróg, z jednej strony wyraźnie wskazywali na wyjątkowy charakter teologii chrześcijańskiej, z drugiej zaś bynajmniej nie stronili ${ }^{24}$ od używania takich czy innych kategorii filozoficznych i poruszania tematów pochodzących z greckiej tradycji filozoficznej ${ }^{25}$. Czyż przedstawiciele ruchu neopatrystycznego nie mogliby, idąc ich śladem, wykorzystywać w swych rozważaniach niektórych wątków opracowanych przez filozofów rosyjskich (którzy, z kolei, w znacznej mierze byli zainspirowani myślicielami greckimi, w duchu głoszonego przez Fłorowskiego „hellenizmu chrześcijańskiego")? Nie ulega wątpliwości, że odpowiedź na jedne i te same pytania może być i faktycznie bywała (jak w przypadku oceny sofiologii) różna (co zresztą jest zwyczajnym zjawiskiem także dla „czystej” filozofii, wolnej od motywów teologicznych), lecz to jeszcze nie powód, by umieszczać teologię i filozofię na dwóch przeciwnych biegunach. Sam Fłorowski zaznaczał, że nawet Tertulian, który często był przedstawiany jako przykład walki teologii z filozofią (w myśl adagio: „Cóż jednak mają wspólnego Ateny z Jerozolimą?”), „nie zdołał uniknąć «badan” i «sporów» i podczas obrony wiary chrześcijańskiej bez wahania odwoływał się do mądrości greckiej"26.

Druga uwaga na temat dokonanej przez Fłorowskiego krytyki renesansu religijno-filozoficznego dotyczy jego skargi o zaniedbaniu w myśli rosyjskiej właściwego dla prawosławia dziedzictwa patrystycznego. Przecież chociażby o. Florenski, starszy kolega i, do pewnego stopnia, kierownik duchowy Fłorowskiego, z którym on korespondował $\mathrm{w}$ czasach gimnazjalnych, nawoływał do odrodzenia tego stylu uprawiania filozofii i teologii, jaki był obecny w czasach ojców Kościoła. Jak słusznie zaznaczył w swej recenzji o. Wojciech

24 Nawet „ostatni” ojciec bizantyjski, uważany za „filar” ortodoksji, jakim był św. Grzegorz Palamas.

25 Zob. T. Obolevitch, Wiedza a wiara w myśli patrystycznej, Kraków 2015 (e-book).

26 Г. Флоровский, Вера и культура, [w:] tegoż, Христианство и иивилизация. Избранные труды по богословию и философии, Санкт-Петербург 2005, s. 663. 
Surówka: „Krytyczne stwierdzenie Fłorowskiego: «Teologii rosyjskiej nie ma i nie było» jest krzywdzące względem ogromnie bogatej twórczości teologicznej jego poprzedników. [...] Jeszcze w XIX wieku istniało w Rosji kilka ośrodków, które zajmowały się myślą ojców Kościoła. Oczywiście mowa tu nie do końca o tym, co miał na myśli Fłorowski, niemniej jednak stwierdzenie, że "powrót do Ojców» zaczyna się od Fłorowskiego, byłoby krzywdzące względem ogromnej pracy dokonanej w teologicznych akademiach Rosji w XIX stuleciu" ${ }^{27}$, w których przecież podjęto trud tłumaczenia i analizy tekstów patrystycznych.

Surówka wskazuje, że początek „renesansu patrystycznego" można datować już na XVIII wiek, kiedy Pasijusz Wieliczkowski przetłumaczył na język rosyjski antologię tekstów $\mathrm{z}$ duchowości wschodniochrześcijańskiej pt. Filokalia ${ }^{28}$. Z kolei działalność translatorska akademii duchownych w XIX wieku sprawiła, że, według słów Borisa Bobrinskoja, „pod koniec XIX w. Rosja dysponowała, w swoim języku, najwspanialszą patrystyczną biblioteką Europy”29. Toteż - dodaje Surówka - „w porównaniu z pracami Wasilia Bołotowa, Niesmiełowa, Michaiła Posnowa, książki Fłorowskiego na temat ojców Kościoła wydają się po prostu skromne"30. W rzeczy samej, nie można powiedzieć, że przed Fłorowskim nie istniały żadne badania poświęcone myśli patrystycznej. Co więcej, sam on „stał na ramionach rosyjskich przedrewolucyjnych badaczy patrystyki" ${ }^{\prime 1}$. W tym sensie omawiany tu autor bezpodstawnie

27 W. Surówka, Podwójny renesans (T. Obolevitch, Filozofia rosyjskiego renesansu patrystycznego, Copernicus Center Press, Kraków 2014), „Logos i Ethos” 1 (2015), s. 178.

${ }_{28}$ Zob. np. książkę współczesnego Fłorowskiemu hieroschimnicha Sergiusza (Czetwierikowa) (1867-1947): прот. С. Четвериков, Стареи Паисий Величковский, Минск 2006, s. 117 $123,143-155$.

${ }_{29}$ B. Bobrinskoj, Aktualna odnowa patrystyki w Kościele prawosławnym, tł. Z. Wójtowicz, „Vox Patrum” 24-29 (1993-1995), s. 18; cyt. za: W. Surówka, Podwójny renesans, dz. cyt., s. 179.

30 W. Surówka, Podwójny renesans, dz. cyt., s. 180.

31 P. L. Gavrilyuk, Florovsky's neopatristic synthesis and the future ways of Orthodox theology, [w:] Orthodox constructions of the West, ed. G. E. Demacopoulos, A. Papanikolaou, BronxNew York 2013, s. 120. 
oceniał stan rosyjskiej teologii jako sformowany całkowicie pod wpływem tradycji zachodniej, a nie bizantyjskiej ${ }^{32}$.

Trzeba jednak zastrzec, że Fłorowski, pisząc, iż linia patrystyczna w Rosji została przerwana, miał na uwadze nie tyle brak przekładów i opracowań dotyczących ojców Kościoła, ile odmienny styl teologii i filozofii Srebrnego Wieku, a mianowicie przesadny racjonalizm, nieuwzględnienie aspektu mistyki, innymi słowy - uprawianie teologii a parte homini, a nie a parte Dei, co jest sprzeczne z jej definicją. Także filozofia - zdaniem Fłorowskiego - nie powinna być traktowana jako autonomiczna dyscyplina będąca owocem „czystego rozumu”, lecz jako synonim teologii. Zaś punktem wyjścia teologii - jak zaznaczył Fłorowski w prywatnej rozmowie z Rudolfem Bultmannem - powinien być nie świat (world), lecz Słowo (word) ${ }^{33}$. Właśnie dlatego myśliciel miał krytyczny stosunek do pism takich uznanych teologów rosyjskich, jak Wiktor Niesmiełow czy Michał Tariejew (nie mówiąc o filozofach Srebrnego Wieku na czele z Sołowjowem). Chodziło mu nie tyle o brak poruszanych w ich pismach wątków patrystycznych, ile o zniekształcenie (w języku Fłorowskiego: pseudomorfozę) stylu patrystycznego, mającego za punkt wyjścia Objawienie i osobiste praktyki religijne. O Sołowjowie pisał, że próbował on „budować synteze kościelna [...] na podstawie doświadczenie niekościelnego" ${ }^{34}$, toteż swoje odejście od Sołowjowa postrzegał jako „osobisty religijny obowiązek i kolejne zadanie współczesnej myśli religijno-filozoficznej”35.

Fłorowski, krytykując niemiecki idealizm, rosyjski renesans religijno-filozoficzny, katolicki neotomizm oraz inne kierunki filozoficzne jako przesadnie racjonalistyczne, zdawał się nie zauważać innych cech,

32 Zob. także P. L. Gavrilyuk, Georges Florovsky and the Russian religious renaissance, dz. cyt., s. 3.

${ }_{33}$ Zob. A. Blane, A sketch of the life of Georges Florovsky, [w:] Georges Florovsky: Russian intellectual and Orthodox churchman, ed. A. Blane, Crestwood 1993, s. 139.

34 Г. Флоровский, Пути русского богословия, dz. суt., s. 311. Zob. А. В. Соболев, Владимир Соловвев и о. Георгий Флоровский. О либерализме и консерватизме в религиознофилософской мысли, [w:] tegoż, О русской философии, Санкт-Петербург 2008, s. 73.

35 List G. Fłorowskiego do o. S. Bułgakowa z 30.12 .1925 („Я не знаю, насколько тверды и самоотверженны миряне парижские...”, dz. суt.), s. 131. 
wspólnych dla tych nurtów i dla wielkich syntez okresu patrystycznego. W filozofii (zwłaszcza historii filozofii) zbyt często występuje pokusa ulegania sztampom, pobieżnym klasyfikacjom takich czy innych autorów jako „idealistów” bądź „materialistów”, „platoników” czy „arystotelików”. Wnikliwa analiza poszczególnych fragmentów konkretnych myślicieli nierzadko pokazuje, że ich poglądy są o wiele bardziej złożone. Nie ulega wątpliwości, że Fłorowski w swych ocenach niejednokrotnie był nazbyt schematyczny, choć jest to do pewnego stopnia zrozumiałe, jeżeli weźmiemy pod uwagę ten fakt, że przysługiwał mu cel „odwrócenia” dotychczasowego toku rozwoju myśli rosyjskiej (i nie tylko) i skierowania jej na tory neopatrystyki. Na tym m.in. polega podstawowa sprzeczność, a przynajmniej niespójność projektu Fłorowskiego: z jednej strony deklarował on wrażliwość na nowe idee i aktualne problemy, gotowość do dialogu z rozmaitymi ideami filozoficznymi (byle dokonywało się to ad mentem patris), z drugiej zaś nie zawsze był tolerancyjny nawet wobec tej tradycji, z której sam wyrósł jako myśliciel, wykazując skłonność do ignorowania i niedoceniania wielu wiodących kierunków współczesnej mu filozofii ${ }^{36}$.

Z tym się wiąże kolejna, trzecia uwaga dotycząca krytyki radykalnego projektu neopatrystyki w wydaniu Fłorowskiego. Mianowicie, zastanawiając się nad zagadnieniem, który z programów wypracowanych przez myślicieli rosyjskich - renesans religijno-filozoficzny czy synteza neopatrystyczna - może odegrać pozytywną rolę we współczesnym postmodernistycznym i postsekularnym społeczeństwie, trzeba zaznaczyć, że oba nurty mają duży potencjał i w związku z tym trzeba traktować je jako strategie komplementarne ${ }^{37}$. W szczególności krytykowana przez Fłorowskiego „szkoła rosyjska” (używając określenia o. Aleksandra Schmemanna ${ }^{38}$ ) wypracowała wiele interesujących i obie-

36 Zob. A. В. Черняев, Г.В. Флоровский как философ и историк русской мысли, Москва 2010, s. 93-94.

37 Zob. N. Asproulis, Is dialogue between Orthodox theology and post-modernity possible? The case of the Russian and neo-patristic schools, „Communio viatorum” 54 (2012) nr 2, s. 221.

38 K. Stöckl, Modernity and its critique in 20th century, "Studies in East European Thought" 58 (2006) nr 4, s. 251. 
cujących idei (w tym koncepcję Sofii) dotyczących filozofii przyrody i relacji między nauką i religią. Ponadto myśliciele renesansu religijno-filozoficznego (zwłaszcza Bierdiajew) w nieporównywalnie większym stopniu podkreślali znaczenie ludzkiej wolności, aniżeli przedstawiciele neopatrystyki ${ }^{39}$.

Po czwarte wreszcie, trzeba dodać, że Fłorowski, postulując odnowienie myśli patrystycznej i stworzenie syntezy neopatrystycznej, sam nie był myślicielem systematycznym ani jako historyk (i krytyk) filozofii rosyjskiej ${ }^{40}$, ani jako twórca projektu neopatrystyki. Nie zaproponował on zwartej koncepcji „hellenizmu chrześcijańskiego”, wymieniając jedynie, jakie cechy powinna posiadać filozofia uprawiana w ramach teologii patrystycznej, m.in. soborowość, hellenizm chrześcijański i historyzm ${ }^{41}$. „Fłorowski rzadko, jeśli w ogóle, mówił o funkcjonowaniu syntezy z należytą metodologiczną precyzją" ${ }^{42}$. Co więcej, to jego prace poświęcone myśli rosyjskiej (zwłaszcza Drogi...), nie bacząc na ich polemiczny charakter (a może właśnie dzięki niemu), odegrały istotną rolę w rozwoju i recepcji filozofii Srebrnego Wieku, podczas gdy opus vitae Fłorowskiego, jakim była neopatrystyka, pozostało w fazie projektu ${ }^{43}$. Rozpaczliwie próbując przekroczyć tradycję Srebrnego Wieku, wciąż znajdował się w orbicie jego oddziaływania.

39 N. Asproulis, Is dialogue between Orthodox theology and post-modernity possible?, dz. cyt., s. 213.

40 Por. А. В. Черняев, Г.В. Флоровский как философ и историк русской мысли, dz. cyt., s. 62-64.

${ }_{41}$ Zob. Г. Флоровский, Пути русского богословия, dz. cyt., s. 496-499.

42 P. L. Gavrilyuk, Georges Florovsky's reading of Maximus: Anti-Bulgakov or pro-Bulgakov?, [w:] Knowing the purpose of creation through the Resurrection: Proceedings of Symposium on St. Maximus the Confessor, ed. M. Vasiljević, Alhambra 2013, s. 409. Por. tenże, Florovsky's neopatristic synthesis and the future ways of Orthodox theology, dz. cyt., s. 102.

43 Synteza neopatrystyczna była budowana przez innych teologów, takich jak Włodzimierz Łosski, John Meyendorff, Paul Evdokimov, a obecnie - Sergiusz Choruży w Rosji, Joanis Ziziulas w Grecji czy Alexei Nesteruk w Anglii. Zob. T. Obolevitch, Filozofia rosyjskiego renesansu patrystycznego, dz. cyt., s. 276-287; П. Гаврилюк, Влияние протоиерея Георгия Флоровского на православное богословие XX века, „Труди Київскої духовної академії” 20 (2014), s. 71-93. 


\section{Status filozofii: Fłorowski i Zieńkowski}

Zastanawiając się nad statutem rosyjskiego renesansu religijno-filozoficznego i syntezy neopatrystycznej, warto zwięźle porównać podejście Fłorowskiego z pozycją innego emigracyjnego myśliciela, Wasyla Zieńkowskiego (1881-1962). Ten ostatni, podobnie jak Fłorowski, przez jakiś czas należał do Bractwa św. Sofii założonego w 1923 roku w Przerowie, publikował w czasopiśmie „Путь”, a także wykładał filozofię, psychologię, apologetykę i historię religii w Instytucie św. Sergiusza w Paryżu (po śmierci o. Bułgakowa pełnił funkcję dziekana uczelni) ${ }^{44}$. Zieńkowski był również członkiem nieformalnego koła patrystyki prowadzonego przez Fłorowskiego w Pradze ${ }^{45}$. Ponadto obu autorów łączyło zainteresowanie historią filozofii rosyjskiej. Byli oni zaangażowani w prace komisji teologicznej rozpatrującej Bułgakowowską sofiologię (1935), aczkolwiek Zieńkowski zajął bardziej umiarkowane stanowisko: „nie ukrywając swych rozbieżności z o. S. Bułgakowem w danej kwestii, poparł ogólny wniosek komisji na temat braku podstaw dla tak surowych oskarżeń pod adresem tego ostatniego" ${ }^{36}$. Kilka lat wcześniej, w 1930 roku Zieńkowski napisał artykuł pt. Przezwyciężenie platonizmu i problem sofijności świata, w którym - podobnie jak Fłorowski w swych wcześniejszych pracach Stworzenie i stworzoność (1927) oraz Idea stworzenia w filozofii chrześcijańskiej (1928) - poruszył temat relacji między Bogiem a światem, broniąc przekonania, że tylko chrześcijańskie pojęcie stworzenia świata pozwala uniknąć pułapki panteizmu ${ }^{47}$. Zarazem

44 В. В. Зеньковский, Мои встречи с вьљающимися людьми, [w:] Из моей жизни. Воспоминания, Москва 2014, s. 331-333.

45 Zob. П. Гаврилюк, Влияние протоиерея Георгия Флоровского на на православное богословие XX века, dz. суt., s. 73. Po raz pierwszy Zieńkowski zetknął się z pismami ojców Kościoła w czasach studenckich, w 1902 roku, przygotowując się do obowiązkowego egzaminu z teologii. Zob. прот. В. В. Зеньковский, Очерк внутренней моей биографии, [w:] Из моей жизни. Воспоминания, dz. суt., s. 368.

46 В. Летцев, „Прежде всего, он искал подлинности...” Очерк жизненного и творческого пути В.В. Зеньковского, Киев 2014, s. 132.

47 Nie sposób omówić tu różnic między Fłorowskim a Zieńkowskim, zaznaczmy tylko, że podczas gdy ten ostatni interpretował relację między Bogiem a światem w kategoriach Sofii nie- 
Zieńkowski bronił o. Bułgakowa przed stawianymi mu zarzutami o brak znajomości dziedzictwa patrystycznego, tłumacząc, że właśnie od niego pożyczał liczne dzieła ojców ${ }^{48}$.

Na szczególną uwagę zasługuje klasyczna już książka Zieńkowskiego Historia filozofii rosyjskiej (t. 1 - 1948, t. 2 - 1950) uchodząca za pierwsze kompletne studium na ten temat. Podczas gdy Fłorowski w swych Drogach teologii rosyjskiej głównie wskazywał na rozmaite mankamenty myśli rosyjskiej, wytykając przede wszystkim liczne zapożyczenia z Zachodu, brak oryginalności i naśladownictwo oraz postulując poszukiwanie nowych ścieżek rozwoju, Zieńkowski zaprezentował jedną z najlepszych syntez całej filozofii rosyjskiej, w tym współczesnego mu renesansu religijno-filozoficznego. W swej Historii starał się przedstawić obiektywny wykład filozofii rosyjskiej, unikając zarówno właściwego dla Fłorowskiego ironizowania, jak i przesadnej obrony rzekomej specyfiki myśli rosyjskiej ${ }^{49}$. Zasłużenie otrzymał za tę pracę stopień doktora filozofii. Aczkolwiek poddał w niej krytyce Sołowjowowską koncepcję wszechjedności ${ }^{50}$ rozwijaną także przez wielu innych myślicieli rosyjskiego renesansu, niemniej jednak na ogół wysoko ocenił samą ideę syntezy filozoficznej, naukowej i religijnej myśli ${ }^{51}$. Taka strategia była dla Fłorowskiego nie do przyjęcia: nie nawoływał on do pojednania filozofii i teologii, lecz głosił postulat zastąpienia czy raczej przezwyciężenia filozofii poprzez tę ostatnią. Zieńkowski

stworzonej i Sofii stworzonej (podobnie jak to czynił S. Bułgakow), Fłorowski, niekiedy używając pojęcia Sofii, daleki był od jego utożsamienia z patrystycznym pojęciem Boskiej energii.

48 Zob. В. Зеньковский, Мое участие в церковной жизни, „Вестник РСХД” 196 (2010), s. 238.

${ }^{49}$ Por. O. T. Ermishin, On two conceptions of Russian philosophy. V. V. Zenkovsky, B. V. Iakovenko, G. G. Shpet, transl. L. E. Wolfson, „Russian Studies in Philosophy” 43 (2004-2005) nr 3, s. 83 .

50 Zob. także jego artykuł Idea wszechjedności Włodzimierza Sołowjowa (1955): В. В. Зеньковский, Идея всеединства в философии Владимира Соловьева, [w:] tegoż, Собрание сочинений, т. 1: О русской философии и литературе. Статьи, очерки и рецензии 1912-1961, Москва 2008, s. 228-245.

${ }_{51}$ Zob. tamże, s. 229, 245; В. В. Зеньковский, История русской философии, т. 2, Москва-Ростов-на-Дону 1999, s. 28-29. 
„zdecydowanie odrzucał rozdźwięk między wiarą a wiedzą"52 i z tej racji rozwijał koncepcję filozofii chrześcijańskiej ${ }^{53}$. Co ciekawe, przy tym powoływał się właśnie na postawę ojców Kościoła, którzy - jak podkreślał - uczyli „o konieczności przywrócenia zatraconej jedności ludzkiego ducha” i rozpatrywał „wszystkie konstrukcje filozoficzne w świetle chrześcijaństwa" ${ }^{4}$. Natomiast Fłorowski (począwszy od eseju pt. Filozofia i religia, 1923) traktował teologię jako jedynie zasadną dziedzinę poznania rzeczywistości Boskiej i jej relacji do świata. Pisał: „Religia i filozofia, wiara i wiedza są różnorodne ze swej natury i są autonomiczne względem siebie" 55 , odrzucając tym samym jakiekolwiek próby budowania niezależnej filozofii chrześcijańskiej. Jego zdaniem filozofia chrześcijańska (czyli „hellenizm chrześcijański”) ma rację bytu tylko jako pochodna czy element teologii.

Zarówno Fłorowski, jak i Zieńkowski odrzucali możliwość racjonalizacji prawd wiary, a więc program, który przyświecał Sołowjowowi i innym przedstawicielom renesansu religijno-filozoficznego. Według słów Fłorowskiego: „«Rozumowe» uzasadnienie wiary jest jej zniszczeniem: wiara uzasadnia sama siebie" ${ }^{36}$, z kolei Zieńkowski argumentował: „to nie wiarę trzeba usprawiedliwiać wobec rozumu, ale odwrotnie, sam rozum potrzebuje olśnienia i oświecenia poprzez

52 В. В. Зеньковский, Основы христианской философии, т. 1, Москва 1997, s. 21.

53 W książce Podstawy filozofii chrześcijańskiej. Pierwszy tom poświęcony gnoseologii ukazał się w 1961 roku, drugi tom nt. kosmologii - dopiero po śmierci autora, w 1964 roku, trzeci tom miał dotyczyć antropologii chrześcijańskiej, lecz Zieńkowski nie zdążył go napisać. Zob. także J. Voskressenskaia, The unity of reason and faith as a human challenge. The problem of Christian culture and philosophy in E. Trubetskoy and V. Zenkovsky, [w:] Faith and reason in Russian thought, red. T. Obolevitch, P. Rojek, Kraków 2015, s. 225-229; O. Ermishin, The problem of Christian culture in the philosophy of Vasily Zenkovsky, [w:] Apology of culture. Religion and culture in Russian thought, ed. A. Mrówczyński-Van Allen, T. Obolevitch, P. Rojek, Eugene 2015, s. 72-78.

54 В. В. Зеньковский, Очерк моей философской системы, „Вестник РСХД” 66-67 (1962), s. 37.

55 Por. Г. В. Флоровский, Философия и религия, „Философские науки” 10 (2013), s. 103 .

56 Tamże. 
wyższe moce" 57 . Z tego względu, podobnie jak Fłorowski, pisał, że w systemie Sołowjowa dostrzec można echa sekularyzmu i modernistycznego panteizmu, co sprawia, że nie można go nazwać „filozofią chrześcijańską" ${ }^{5}$. W myśli Sołowjowa to „nie chrześcijańska doktryna zostaje ubogacona dzięki filozofii, a odwrotnie, do filozofii zostają wprowadzone idee chrześcijańskie" 59 . Jak widać, ocena ta jest bardzo zbliżona do diagnozy Fłorowskiego.

A zatem Fłorowski i Zieńkowski - autorzy, którzy położyli fundament pod badania myśli rosyjskiej - zgadzali się co do ogólnego kierunku jej rozwoju: miał on być związany z poszukiwaniem korzeni wschodniochrześcijańskich i przezwyciężeniem racjonalistycznego podejścia właściwego dla myśli zachodniej (oraz wielu rosyjskich filozofów Srebrnego Wieku). W duchu Fłorowskiego Zieńkowski twierdził, że współczesne mu czasy cechują się pragnieniem odnowy religijnej i „odnowienia umysłu”, o którym pisali jeszcze XIX-wieczni słowianofile ${ }^{60}$. Zarazem analizowani tu autorzy nieco inaczej rozumieli, na czym ma polegać upragniona odnowa: podczas gdy Zieńkowski uważał, że należy nadal rozwijać filozofię, aczkolwiek oczyszczoną od wszelkich przejawów sekularyzmu i racjonalizmu (mówiąc ogólnie - „modernizmu”), Fłorowski proponował zwrócić się w stronę teologii uprawianej w duchu ojców Kościoła i dopiero w jej łonie rozwijać „hellenizm chrześcijański”, który - jak wskazuje na to zachowany testament teologiczny myśliciela - rozumiał dosłownie, czyli jako zwrócenie się do myśli greckich ojców Kościoła, z wykluczeniem próby nawiązania dialogu z jakimikolwiek współczesnymi filozofami (w tym rosyjskimi $)^{61}$.

57 В. В. Зеньковский, Идея всеединства в философии Владимира Соловьева, dz. cyt., s. 229.

58 Zob. tenże, История русской философии, т. 2, dz. суt., s. 31, 75, 77; tenże, Очерк моей философской системы, dz. суt., s. 38.

59 Por. tenże, История русской философии, т. 2, dz. суt., s. 76.

60 Tenże, Нама эпоха, [w:] tegoż, Собрание сочинениц̆, т. 2: О православии и религиозной культуре. Статьи и очерки 1916-1957, Москва 2008, s. 406.

${ }_{61}$ Zob. P. Gavrilyuk, Florovsky's neopatristic synthesis and the future ways of Orthodox theology, dz. cyt., s. 116. 


\section{Zakończenie}

Rosyjski renesans religijno-filozoficzny należy do przeszłości ${ }^{62}$, podczas gdy rozmaite próby stworzenia syntezy (czy syntez) neopatrystycznych trwają do dziśs ${ }^{63}$. Czy oznacza to, że Fłorowski był dalekowzrocznym autorem czy wręcz prorokiem, który wyznaczył nową epokę w rozwoju myśli? Owszem, słusznie wskazał on na pilną potrzebę odrodzenia myśli ojców Kościoła (zresztą, jak to zostało zaznaczono wyżej, nie był w tym odosobniony ${ }^{64}$ ), mimo że nie docenił możliwości, jakie niesie z sobą - także dla postulowanej odnowy patrystycznej - filozofia rosyjska Srebrnego Wieku. Trzeba nadto odnotować fakt, że na „wymarcie” renesansu religijno-filozoficznego złożyło się szereg czynników, których nie sposób tu dokładnie przeanalizować ${ }^{65}$. Tak czy inaczej, dzisiejsza filozofia rosyjska znajduje się w impasie: istnieje wprawdzie sporo wybitnych badaczy-historyków, brakuje jednak samodzielnych, oryginalnych twórców. Najbardziej ciekawe i obiecujące próby faktycznie podejmowane są przez przedstawicieli ruchu neopatrystycznego (na uwagę zasługują tacy autorzy, jak wspomniany już Grek Joanis Zizioulas oraz Christos Jannaras, uważani za najznakomitszych współczesnych prawosławnych myślicieli).

Czy filozofia uprawiana na gruncie wschodniochrześcijańskim rzeczywiście musiała powrócić do teologii, jak tego chciał Fłorowski, czy

62 Uważa się, że datę graniczną wyznacza rok 1950, a najpóźniej 1954 - rok śmierci jego ostatnich przedstawicieli, Iwana Iljina i Borysa Wyszesławcewa. Zob. S. Mazurek, Rosyjski renesans religijno-filozoficzny. Próba syntezy, Warszawa 2008, s. 222.

63 Istnieją jednak opinie, że samo słowo „neopatrystyka” jest oksymoronem i że raczej należy mówić o „post-patrystyce”. Zob. Э. Лаут, Пост-патристическое богословие, или за пределами неопатристического синтеза, http://www.bogoslov.ru/text/1982765.html.

${ }_{64}$ Przed Fłorowskim nad przywróceniem zapomnianego dziedzictwa patrystycznego pracował o. Wasili Kriwoszein (nota bene mający krytyczny stosunek do postulatu Fłorowskiego). Należy też pamiętać o podobnej tendencji obecnej w latach 30-50. XX wieku wśród katolickich i protestanckich teologów.

65 Niektóre powody zaniku rosyjskiego renesansu religijno-filozoficznego podaje Stanisław Mazurek (S. Mazurek, Rosyjski renesans religijno-filozoficzny, dz. cyt., s. 230-232), choć problem ten wciąż czeka na zgłębienie. 
raczej nie wykorzystuje w pełni swego potencjału (zwłaszcza zawartego w niej elementu religijnego bądź fermentu chrześcijańskiego) w dobie współczesnej? Pytanie to pozostawiamy bez odpowiedzi, zapraszając Czytelnika do dalszej dyskusji.

\section{Bibliografia}

Asproulis N., Is dialogue between orthodox theology and post-modernity possible? The case of the Russian and neo-patristic schools, „Communio viatorum” 54 (2012) nr 2, s. 203-222.

Blane A., A sketch of the life of Georges Florovsky, [w:] Georges Florovsky, Russian intellectual and Orthodox churchman, ed. A. Blane, Crestwood 1993, s. 11-217.

Ermishin O., The problem of Christian culture in the philosophy of Vasily Zenkovsky, [w:] Apology of culture. Religion and culture in Russian thought, ed. A. Mrówczyński-Van Allen, T. Obolevitch, P. Rojek, Eugene 2015, s. 72-78.

Ermishin O. T., On two conceptions of Russian philosophy. V.V. Zenkovsky, B. V. Iakovenko, G.G. Shpet, trans. L. E. Wolfson, „Russian Studies in Philosophy” 43 (2004-2005) nr 3, s. 81-89.

Gavrilyuk P. L., Florovsky's neopatristic synthesis and the future ways of Orthodox theology, [w:] Orthodox constructions of the West, ed. G. E. Demacopoulos, A. Papanikolaou, Bronx-New York 2013, s. 102-124.

Gavrilyuk P. L., Georges Florovsky and the Russian religious renaissance, Oxford 2013.

Gavrilyuk P. L., Georges Florovsky's reading of Maximus: anti-Bulgakov or pro-Bulgakov?, [w:] Knowing the purpose of creation through the resurrection: Proceedings of symposium on St. Maximus the Confessor, ed. M. Vasiljević, Alhambra 2013, s. 407-415.

Kroczak J., Palamas i Florenski. Metafizyka serca w patrystycznej i rosyjskiej tradycji filozoficznej i literackiej, [w:] Metafizyka a literatura w kulturze rosyjskiej. Метафизика и литература в русской культуре, red. T. Obolevitch, Kraków 2012, s. 311-326.

Leonkiewicz Ł., Czy neopatrystyka była rosyjskim renesansem patrystycznym, http:// www.ccpress.pl/recenzje/_Filozofia_rosyjskiego_renesansu_patrystycznego__rec._ks._dr._Lukasza_Leonkiewicza_81 (01.04.2015).

Mazurek S., Rosyjski renesans religijno-filozoficzny. Próba syntezy, Warszawa 2008. 
Obolevitch T., Filozofia rosyjskiego renesansu patrystycznego: o. Gieorgij Fłorowski, Włodzimierz Łosski i inni, Kraków 2014.

Obolevitch T., Wiedza a wiara w myśli patrystycznej, Kraków 2015 (e-book).

Sauvé R. J., Florovsky's tradition, „Greek Orthodox Theological Review” 55 (2010) nr $1-4$, s. 213-241.

Stöckl K., Modernity and its critique in 20th century, „Studies in East European Thought” 58 (2006) nr 4, s. 243-269.

Surówka W., Podwójny renesans (T. Obolevitch, Filozofia rosyjskiego renesansu patrystycznego, Copernicus Center Press, Kraków 2014), „Logos i Ethos” 1 (2015), s. 167-181.

Voskressenskaia J., The unity of reason and faith as a human challenge. The problem of Christian culture and philosophy in E. Trubetskoy and V. Zenkovsky, [w:] Faith and reason in Russian thought, red. T. Obolevitch, P. Rojek, Kraków 2015, s. 225-229.

Визгин В. П., Экзистенциализм и богословская мысль Георгия Флоровского, „Философский журнал" 2 (2014), s. 24-37.

Гаврилюк П., Влияние протоиерея Георгия Флоровского на православное богословие ХХ века, „Труди Київскої духовної академії” 20 (2014), s. 71-93.

Гаврилюк П. Л., Неизвестная странииа историко-философского наследия Г.В. Флоровского, [w:] Историко-философский ежегодник 2013, ред. А.В. Черняев, Москва 2014, s. 304-311.

Зеньковский В., Мое участие в церковной жизни, „Вестник РСХД” 196 (2010), s. 225-239.

Зеньковский В., Очерк внутренней моей биографии, „Вестник РСХД” 66-67 (1962), s. 8-15.

Зеньковский В. В., Идея всеединства в философии Владимира Соловьева, [w:] tegоż, Собрание сочинений, т. 1: О русской философии и литературе. Статьи, очерки и рещензии 1912-1961, Москва 2008, s. 228-245.

Зеньковский В. В., История русской философии, т. 2, Москва-Ростов-на-Дону 1999.

Зеньковский В. В., Наша эпоха, [w:] tegoż, Собрание сочинений, т. 2: О правоставии и религиозной культуре. Статьи и очерки 1916-1957, Москва 2008, s. 402-449.

Зеньковский В. В., Основы христианской философии, т. 1, Москва 1997.

Зеньковский В. В., Очерк моей философской системьы, „Вестник РСХД” 66-67 (1962), s. 37-38.

Лаут Э., Пост-патристическое богословие, или за пределами неопатристического синтеза, http://www.bogoslov.ru/text/1982765.html. 
Летцев В., „Прежде всего, он искал подлинности...” Очерк жизненного и творческого пути В.В. Зеньковского, Киев 2014.

Письма Владимира Сергеевича Соловьева, т. 3, Брюссель 1970.

Соболев А. В., Владимир Соловьев и о. Георгий Флоровский. О либерализме и консерватизме в религиозно-философской мысли, [w:] tegoż, О русской философии, Санкт-Петербург 2008, s. 65-76.

Соловьев В. С., История и будущность теократии, [w:] Собрание сочинений Владимира Сергеевича Соловьева, т. 4, Брюссель 1966, s. 214-582.

Флоровский Г., Вера и культура, [w:] tegoż, Христианство и цзивилизация. Избранные труды по богословию и философии, Санкт-Петербург 2005, s. 650-670. Флоровский Г., Пути русского богословия, Минск 2006.

Флоровский Г. В., Русская философия в эмиграции, [w:] Историко-философский ежегодник 2013, ред. А. В. Черняев, Москва 2014, s. 314-337.

Флоровский Г. В., Философия и религия, „Философские науки” 10 (2013), s. 101-105.

Черняев А. В., Г. В. Флоровский как философ и историк русской мысли, Москва 2010.

Четвериков С., Стареи, Паисий Величковский, Минск 2006.

„Я не знаю, насколько тверды и самоотверженны миряне парижские...”: пятнадцать писем друг другу. Письма. Г.В. Флоровский - о. С. Булгакову (1925-1943), [w:] Софиология и неопатристический синтез. Богословские итоги фитософского развития, ред. К. М. Антонов, Н. А. Ваганова, Москва 2013, s. 115-128. 